OPEN ACCESS

Edited by:

Nurit Hollander,

Tel Aviv University, Israel

Reviewed by:

Manfred B. Lutz,

University of Wuerzburg, Germany

Walter J. Storkus,

University of Pittsburgh, USA

*Correspondence:

Brian J. Czerniecki,

Department of Surgery, University of

Pennsylvania Perelman School of Medicine, 3400 Civic Center Drive,

Philadelphia, PA 19104, USA

brian.czerniecki@uphs.upenn.edu

Specialty section:

This article was submitted to

Immunotherapies and Vaccines,

a section of the journal

Frontiers in Immunology

Received: 23 April 2015

Accepted: 15 May 2015

Published: 02 June 2015

Citation:

Datta J, Berk E, Cintolo JA, Xu S, Roses RE and Czerniecki BJ (2015)

Rationale for a multimodality strategy to enhance the efficacy of dendritic cell-based cancer immunotherapy.

Front. Immunol. 6:271.

doi: 10.3389/fimmu.2015.00271

\section{Rationale for a multimodality strategy to enhance the efficacy of dendritic cell-based cancer immunotherapy}

\author{
Jashodeep Datta ${ }^{1}$, Erik Berk ${ }^{1}$, Jessica A. Cintolo ${ }^{1}$, Shuwen Xu ${ }^{1}$, Robert E. Roses ${ }^{1}$ and \\ Brian J. Czerniecki ${ }^{1,2 *}$ \\ ${ }^{1}$ Division of Endocrine and Oncologic Surgery, Department of Surgery, University of Pennsylvania Perelman School of Medicine, \\ Philadelphia, PA, USA, ${ }^{2}$ Rena Rowen Breast Center, Hospital of the University of Pennsylvania, Philadelphia, PA, USA
}

Dendritic cells (DC), master antigen-presenting cells that orchestrate interactions between the adaptive and innate immune arms, are increasingly utilized in cancer immunotherapy. Despite remarkable progress in our understanding of DC immunobiology, as well as several encouraging clinical applications - such as DC-based sipuleucel-T for metastatic castration-resistant prostate cancer - clinically effective DC-based immunotherapy as monotherapy for a majority of tumors remains a distant goal. The complex interplay between diverse molecular and immune processes that govern resistance to DC-based vaccination compels a multimodality approach, encompassing a growing arsenal of antitumor agents which target these distinct processes and synergistically enhance DC function. These include antibody-based targeted molecular therapies, immune checkpoint inhibitors, therapies that inhibit immunosuppressive cellular elements, conventional cytotoxic modalities, and immune potentiating adjuvants. It is likely that in the emerging era of "precision" cancer therapeutics, tangible clinical benefits will only be realized with a multifaceted - and personalized - approach combining DC-based vaccination with adjunctive strategies.

Keywords: dendritic cell, immunotherapy, multimodality, adoptive cell therapy, targeted therapy, checkpoint inhibitor, chemotherapy, radiotherapy

\section{Introduction}

Dendritic cells (DCs) function at the interface of the innate and adaptive immune systems, making them uniquely suited for cancer immunotherapy. As sentinel members of the innate immune arm, DCs elaborate protective cytokines (i.e., IL-6, IL-12) in response to "danger" signals (1). As master antigen-presenting cells (APC), DCs capture, process, and present antigens in the context of major histocompatibility (MHC) molecules to naïve T-cells at lymphoid organs, thereby inducing adaptive $\mathrm{CD}^{+}$and $\mathrm{CD}^{+}$T-cell-mediated immune responses $(2,3)$; indeed, DCs' potency for inducing T-cell proliferation is 10-100 times that of B-cells or monocytes (4).

\footnotetext{
Abbreviations: 1-MT, 1-methyl-D-tryptophan; CTL, cytotoxic T-lymphocyte; CYC, cyclophosphamide; DC, dendritic cell; ID, intradermal; IDO, indoleamine-2,3-dioxygenase; IN, intranodal; GrB, granzyme-B; HER2, human epidermal growth factor receptor-2 (representative of receptor tyrosine kinase family); $\mathrm{mAb}$, monoclonal antibody; MDSC, myeloid-derived suppressor cells; MHC/Ag, antigen presented in the context of MHC molecules; moDC, monocyte-derived DC; NK, natural killer cell; NKT, natural killer T-cell; PDGFR, platelet derived growth factor receptor; SC, subcutaneous; TCR, T-cell receptor; $\mathrm{T}_{\text {reg, }}$, regulatory T-cell; VEGFR, vascular endothelial growth factor receptor.
} 
Unique properties make DCs particularly attractive vehicles for immunotherapy. These include their ability to cross-present (i.e., re-route exogenous antigens typically presented on MHC class II molecules into pathways for class I presentation) (5), induce natural killer (NK) or NK T-cell responses $(6,7)$, and potentiate antitumor humoral responses (8). More importantly, plasticity of DC lineage and the ability to direct DC activation with external signals [e.g., Toll-like receptor (TLR) agonists], which polarize ensuing $\mathrm{T}$-cell responses, can be harnessed for therapeutic application in DC-based approaches (9).

Following the initial promise of DC-based vaccination attempts in lymphoma and melanoma patients $(10,11)$, autologous DCs have been employed in immunotherapy for several tumor types, including melanoma, prostate cancer, renal cell carcinoma (RCC), and glioblastoma with varying success. A majority of these trials indicate that DC-based immunotherapy, while tolerable and strongly immunogenic, fails to achieve meaningful objective response rates (12). These data, along with the remarkable diversity of cytokine activation regimens, DC maturation states, and antigen loading strategies employed in DC vaccine design (9), reflect an evolving - but incomplete - understanding of optimal DC immunobiology. As such, despite recent FDA approval of sipuleucel-T - blood DCs pulsed with prostatic acid phosphataseGM-CSF fusion protein - for metastatic castration-resistant prostate cancer (13), clinically effective DC immunotherapy as monotherapy for a majority of solid tumors remains a distant goal.

There is emerging evidence that the maximal benefit of DCbased immunotherapy may be achieved in combination with other antitumor therapies that augment DC function (Table 1; Figure 1). In this review, we explore the biologic rationale for such multimodality approaches to optimize the impact of current DC-based cancer immunotherapy.

\section{Improving Efficacy of Existing DC-Based Vaccines}

Traditionally, two DC-based vaccination approaches have been widely used: direct targeting of antigens to DC receptors in vivo, and ex vivo-generated antigen-loaded DCs. Beyond these approaches - reviewed extensively elsewhere (14) - our growing understanding of DC biology highlights potential strategies to improve DC-based vaccine efficacy: (a) exploiting diversity of DC lineage [i.e., plasmacytoid DCs (15), CD141 ${ }^{+}$DCs (16)] to improve antigen cross-presentation and potency of cytotoxic $\mathrm{CD}^{+}$T-lymphocyte (CTL) responses; (b) silencing of antigen presentation "attenuators" [e.g., inhibition of SOCS1 (17)] to enhance DC function by controlling the tolerogenic state of DCs and magnitude of antigen presentation; (c) synergizing with adoptive cell therapy [e.g., DC vaccine-primed peripheral blood T-cells expanded ex vivo with CD3/CD28 co-stimulation (18)]; (d) manipulating ex vivo DC maturation conditions to enhance immunogenicity [e.g., utilizing IL-15 to generate Langerhans-type DCs (19), or IFN- $\gamma$ and lipopolysaccharide (LPS, a TLR4 agonist) to yield type 1-polarized DCs (DC1) (20)]; and (e) modification of co-stimulatory molecule expression to improve DC potency [e.g., mRNA-electroporated DCs encoding CD40L, CD70, and TLR4 (21)].
Three such strategies merit discussion. Adoptive cell therapy (ACT) encompasses infusion of in vitro-expanded tumorinfiltrating lymphocytes (TILs) (22-24) or T-cells genetically engineered to harbor T-cell receptors (TCR) - and more recently chimeric antigen receptors (CAR) - specific for tumor-associated antigens $(25,26)$. While promising, ACT is rarely effective as monotherapy for a majority of tumors; moreover, immune "conditioning" with lymphodepleting chemotherapy (see Section "Cytotoxic Chemotherapy"), total body irradiation, or in vivo IL-2 support is needed in order to optimize antitumor efficacy (27). An alternative to these toxic conditioning regimens may be provision of antigen in the form of peripheral DC vaccination, a premise that is supported by several preclinical models (28-31) and early in-human trials $(27,32)$. Antigen-pulsed DC vaccination may potentiate the proliferation, persistence, and selective migration of transferred T-cells to tumor sites (28). Moreover, the magnitude of the polarized ACT T-cell response may be augmented by DC vaccination via provision of co-stimulatory signals (18). Several trials investigating such combinations are currently underway (Table 1).

While the optimal DC phenotype for cancer immunotherapy remains controversial, it is increasingly recognized that incorporation of IL-12p70-producing DC1 - which subsequently polarize naïve $\mathrm{CD}^{+}{ }^{+}$T-cells toward a IFN- $\gamma$ and TNF- $\alpha$-secreting T-helper type 1 (Th1) phenotype (20) - appears advantageous. Our group (33), as well as others (34), employs a streamlined recipe of IFN- $\gamma$ and LPS to generate high IL-12p70producing DC1. IL-12p70 - predictive of favorable outcomes in melanoma (35) and glioblastoma (36) patients - promotes NK cell activation (37) and possesses anti-angiogenic properties (38). In our studies, $\mathrm{CD}^{+}$T-cells could only recognize HLA-A2 ${ }^{\text {pos }}$ cancer cells if sensitizing DCs secreted IL12 p70 (39). Furthermore, Th1-derived IFN- $\gamma /$ TNF- $\alpha$ are critically important for tumor rejection in preclinical models (40) and synergistically induce apoptosis of tumor cells in vitro (41). Generation of Th1 subsets offers other advantages: Th1-driven CTLs detect class I-tumor antigen complexes with higher affinity than Th2-driven counterparts (42), and are instrumental in B-cell responses by inducing antibody class-switching and IgG production (4).

A potential drawback of DC maturation with IFN- $\gamma / \mathrm{LPS}$ regimens is the narrow temporal window for IL-12p70 secretion secretion commences around $6 \mathrm{~h}$ after IFN- $\gamma / \mathrm{LPS}$ activation; production is maximized - so-called "burst" - around $8-10 \mathrm{~h}$ but is virtually exhausted $16-24 \mathrm{~h}$ later (20). Vaccination with such exhausted DCs would likely polarize tolerogenic (e.g., Th2) Tcell responses (43), resulting in suboptimal clinical outcomes. Moreover, IFN- $\gamma /$ LPS activation generates DCs which lack CCR7 and CXCR-4 chemokine expression, limiting their "trafficking" ability to lymphoid organs (44). To overcome these limitations, our group employs a protocol whereby DCs are: (a) harvested $6 \mathrm{~h}$ after LPS activation, prior to IL-12p70 secretory "burst;" and (b) injected intranodally via ultrasound guidance in order to colocalize IL-12p70 "burst" with the anatomic site of T-cell sensitization $(20,45,46)$. In general, vaccine design must exploit such pre-programed cytokine secretion schedules in order to optimize in vivo $\mathrm{DC}$ efficacy. 
TABLE 1 | Multimodality strategy to enhance the efficacy of dendritic cell-based vaccination.

\begin{tabular}{|c|c|c|c|}
\hline Strategy & $\begin{array}{l}\text { Agent/technique } \\
\text { utilized }\end{array}$ & Proposed advantage(s) & Clinical trial(s) completed/underway, if applicable \\
\hline \multirow[t]{2}{*}{$\begin{array}{l}\text { Adoptive cell } \\
\text { therapy }(\mathrm{ACT})\end{array}$} & Autologous T-cells/TIL & $\begin{array}{l}\text { Fewer adverse effects, } \\
\text { circumvent need for } \\
\text { pre-conditioning with } \\
\text { chemotherapy, IL-2, etc. }\end{array}$ & $\begin{array}{l}\text { Melanoma (NCT01946373, NCT00338377, NCT00910650, NCT00313508, } \\
\text { NCT00961844, NCT01339663); Brain (NCT00693095, NCT01759810); } \\
\text { Breast (NCT01782274); Lung (NCT01782287, NCT00776295) }\end{array}$ \\
\hline & $\begin{array}{l}\text { Genetically engineered } \\
\text { TCR or CAR T-cells }\end{array}$ & $\begin{array}{l}\text { Synergistically enhance antigen } \\
\text { targeting and DC function }\end{array}$ & Melanoma (NCT00910650); Solid (NCT00704938, NCT01697527) \\
\hline \multirow{4}{*}{$\begin{array}{l}\text { Targeted } \\
\text { therapies }\end{array}$} & Sunitinib & Inhibits MDSC, depletes & Renal (NCT01582672, NCT00678119) \\
\hline & Dasatinib & CTLA-4/PD-1 & Melanoma (NCT01876212) \\
\hline & Trastuzumab & $\begin{array}{l}\text { Potentiate CTLs, enhance } \\
\text { ADCC }\end{array}$ & Breast (NCT00088985, NCT00266110, NCT02336984) \\
\hline & Vemurafenib & Potentiate DC function & - \\
\hline \multirow{2}{*}{$\begin{array}{l}\text { Targeting immune } \\
\text { checkpoint } \\
\text { pathways }\end{array}$} & Anti-CTLA4 & Inhibit CTLA-4:B7 & Melanoma (NCT00090896) \\
\hline & Anti-PD-1 & Impair PD-1:CTL interaction & $\begin{array}{l}\text { Renal (NCT01441765); Prostate (NCT01420965); Hematological } \\
\text { (NCT01096602, NCT01067287) }\end{array}$ \\
\hline \multirow{5}{*}{$\begin{array}{l}\text { Muting immuno- } \\
\text { suppressive } \\
\text { cellular elements }\end{array}$} & $\begin{array}{l}\text { Anti-CD25 (basiliximab, } \\
\text { daclizumab) mAb }\end{array}$ & Deplete $T_{\text {reg }}$ & $\begin{array}{l}\text { Brain (NCT00626483); Melanoma (NCT00847106); Ovarian } \\
\text { (NCT01132014) }\end{array}$ \\
\hline & $\begin{array}{l}\text { Denileukin diftitox } \\
\text { 1-methyl-d-tryptophan }\end{array}$ & $\begin{array}{l}\text { Target CD25, deplete } T_{\text {reg }} \\
\text { Inhibits } \\
\text { indoleamine-2,3-dioxygenase }\end{array}$ & $\begin{array}{l}\text { Melanoma (NCT00056134); Ovarian (NCT00703105); Solid (NCT00128622) } \\
\text { Breast (NCT01042535) }\end{array}$ \\
\hline & All-trans retinoic acid & $\begin{array}{l}\text { MDSC differentiation into } \\
\text { non-suppressive cells }\end{array}$ & Lung (NCT00617409) \\
\hline & $\begin{array}{l}\text { COX-2 inhibitors } \\
\text { (celecoxib, meloxicam) }\end{array}$ & $\begin{array}{l}\text { Inhibit CCL2, upregulate } \\
\text { CXCL10 }\end{array}$ & $\begin{array}{l}\text { Melanoma (NCT00197912); Head and Neck (NCTO0589186); Brain } \\
\text { (NCT01759810); Lung (NCT00442754, NCT01782287); Breast } \\
\text { (NCT01782274) }\end{array}$ \\
\hline & Anti-VEGF & Inhibit MDSC & $\begin{array}{l}\text { Renal (NCT00913913); Prostate (NCT00027599); Ovarian (NCT00683241 } \\
\text { NCT01132014) }\end{array}$ \\
\hline \multirow[t]{4}{*}{ Chemotherapy } & $\begin{array}{l}\text { Cyclophosphamide } \pm \\
\text { fludarabine }\end{array}$ & $\begin{array}{l}\text { Lymphodepleting, reboots } \\
\text { immune system }\end{array}$ & $\begin{array}{l}\text { Solid (NCT01697527); Brain (NCT00323115, NCT02010606); Melanoma } \\
\text { (NCT00338377, NCT00910650, NCT01946373, NCT00313508, } \\
\text { NCT00704938); Renal (NCT00704938, NCT00093522) }\end{array}$ \\
\hline & $\begin{array}{l}\text { Metronomically dosed } \\
\text { cyclophosphamide }\end{array}$ & $\begin{array}{l}\text { Depletes } \mathrm{T}_{\text {reg }} / \mathrm{MDSC} \text {, } \\
\text { potentiates Th1 }\end{array}$ & $\begin{array}{l}\text { Head and Neck (NCT01149902); Lung (NCT01159288); Melanoma } \\
\text { (NCT00197912, NCT00683670, NCT00722098, NCT00978913, } \\
\text { NCT00313235, NCT01339663; NCT00610389), Mesothelioma } \\
\text { (NCT01241682); Ovarian (NCT00683241, NCT00478452); Prostate } \\
\text { (NCT01339663); Renal (NCT00610389) }\end{array}$ \\
\hline & Gemcitabine & $\begin{array}{l}\text { Improves cross-presentation, } \\
T_{\text {eff }} \text { infiltration }\end{array}$ & Pancreatic (NCT00547144); Sarcoma (NCT01803152) \\
\hline & Temozolomide & $\begin{array}{l}\text { Immune recovery cytokine } \\
\text { environment }\end{array}$ & $\begin{array}{l}\text { Brain (NCT00323115, NCT01213407, NCT01567202, NCT00639639); } \\
\text { Melanoma (NCT00961844) }\end{array}$ \\
\hline Radiotherapy & Radiotherapy & $\begin{array}{l}\text { Enhances tumor } \\
\text { immunogenicity, releases TLR } \\
\text { agonists, targets stroma, } \\
\text { abscopal effect }\end{array}$ & $\begin{array}{l}\text { Brain (NCT00323115, NCT01213407, NCT01567202); Breast } \\
\text { (NCT00082641); Esophageal (NCT01691625); Melanoma (NCT00278018); } \\
\text { Pancreatic (NCT00547144, NCT00843830); Sarcoma (NCT00365872, } \\
\text { NCT01347034) }\end{array}$ \\
\hline \multirow[t]{9}{*}{$\begin{array}{l}\text { Cytokines and } \\
\text { TLR agonists }\end{array}$} & $\mathrm{IL}-2$ & $\begin{array}{l}\text { Protect CTL effectors from } \\
\text { tumor-mediated dysfunction }\end{array}$ & $\begin{array}{l}\text { Brain (NCT01235845); Breast (NCT00197925); Colorectal (NCT00176761, } \\
\text { NCT0001959); Lung (NCT00442754); Melanoma (NCT00197912, } \\
\text { NCT00338377, NCT00910650, NCT00279058, NCT00006113, } \\
\text { NCT00004025, NCT01339663, NCT00003229, NCT00019214, } \\
\text { NCT00704938); Renal (NCT00197860, NCT00913913, NCT00085436, } \\
\text { NCT00704938); Sarcoma (NCT00001566); Lymphoma (NCT00006434) }\end{array}$ \\
\hline & $\begin{array}{l}\text { Poly-I:C or derivatives } \\
\text { (TLR3) }\end{array}$ & DC activation, $T_{\text {eff }}$ infiltration & $\begin{array}{l}\text { Melanoma (NCT00278018, NCT00610389); Renal (NCT00913913, } \\
\text { NCT00085436, NCT00610389) }\end{array}$ \\
\hline & IFN- $\alpha$ & Induce apoptosis of tumor & Myeloma (NCT00616720) \\
\hline & $\mathrm{IFN}-\gamma$ & Cytotoxic, polarize Th1 & Pediatric Solid Tumors (NCT00923351) \\
\hline & $\mathrm{IL}-7$ & Maintenance of DCs & Breast (NCT00622401) \\
\hline & $\mathrm{IL}-12$ & Polarize Th1, anti-angiogenic & $\begin{array}{l}\text { Brain (NCT01808820, NCT01792505, NCT01171469); Lung } \\
\text { (NCT00442754); Ovarian (NCT00799110); Sarcoma (NCT01803152, } \\
\text { NCT01241162, NCT00944580) }\end{array}$ \\
\hline & Imiquimod (TLR7) & $\begin{array}{l}\text { Induced type 1-IFN by } \\
\text { plasmacytoid DCs }\end{array}$ & $\begin{array}{l}\text { Brain (NCT01204684, NCTO0766753); Melanoma (NCT01783431); } \\
\text { Pancreatic (NCT01677962, NCT01410968); Solid (NCT01734564, } \\
\text { NCT02151448) }\end{array}$ \\
\hline & Resiquimod (TLR7/8) & $T_{\text {eff }}$ infiltration, inhibit $T_{\text {reg }}$ & Brain (NCT01204684) \\
\hline & Thymosin- $\alpha-1$ (TLR9) & Potentiate CTL responses & Renal (NCT00197860) \\
\hline
\end{tabular}

Clinical trials utilizing the respective approach are listed, if applicable.

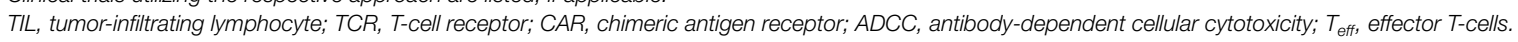




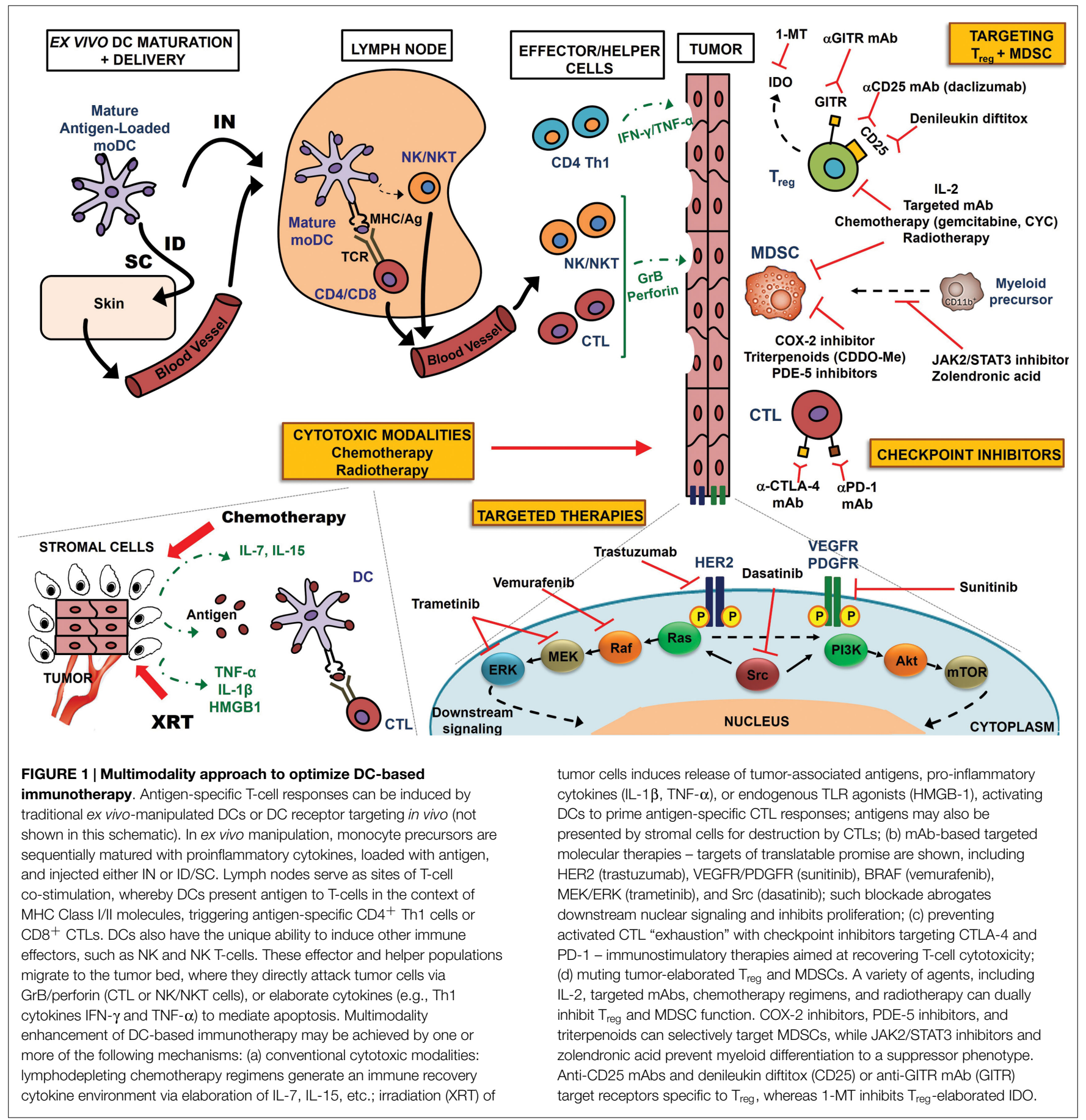

IFN- $\gamma /$ LPS-activated DCs are also capable of a second IL-12p70 burst in vivo following restimulation in lymph nodes by activated $\mathrm{CD}^{+}{ }^{+}$T-helper (Th) cells via CD40-CD40L interactions $(20,46)$. Beyond perpetuation of IL-12p70 secretion, CD40 triggering is critical in upregulating co-stimulatory molecule expression (i.e., CD80, CD86) on DCs, promoting cross-priming to exogenous antigens, augmenting $\mathrm{CD}^{+}{ }^{+}$and $\mathrm{CD} 8^{+}$T-cell expansion, rescuing $\mathrm{CD}^{+}$T-cell exhaustion, and mediating resistance of mature DCs to suppression by regulatory $\mathrm{T}$-cells $\left(\mathrm{T}_{\text {reg }}\right)$
(47-53). Notably, CD40-CD40L interaction - but not TLR4 signaling via LPS - can restore the capacity for IL-12p70 secretion in IFN- $\gamma /$ LPS-activated DCs which have exhausted their potential for cytokine secretion $(54,55)$. Consequently, incorporation of CD40 ligation has emerged as an attractive strategy to enhance DC potency. For instance, autologous DCs electroporated with mRNA encoding CD40L (plus CD70 and TLR4) and fusion protein of an HLA class II-targeting signal (DCLAMP) and melanoma-associated antigens (TriMixDC-MEL) 
were immunogenic and generated tumor responses in chemorefractory melanoma $(21,56)$.

\section{Targeted Molecular Therapies}

The advent of molecular therapies targeting tumor oncogene drivers represents one of the most significant advances in contemporary cancer therapy. Despite encouraging success in many tumors types, however, disease relapse is observed in a sizeable proportion of patients treated with these agents. Novel combinations of targeted therapies with immune interventions, therefore, are conceptually appealing and are being increasingly explored in order to reduce treatment failures (57). A particularly promising candidate is sunitinib, a receptor tyrosine kinase (RTK) inhibitor targeting VEGFR, PDGFR, c-KIT, and Flt-3; in preclinical models, sunitinib decreased tumor microenvironment (TME) accumulation of myeloid-derived suppressor cells (MDSCs), restored Th1/CTL functionality, muted PD-L1 expression on tumor-resident DCs, depleted CTLA-4/PD-1 expression on activated CTLs, and inhibited production of inhibitory IL-10, TGF- $\beta$, and FoxP3 from TILs $(58,59)$. In a phase II clinical trial, administration of sunitinib with DCs co-electroporated with amplified tumor and synthetic CD40L mRNA yielded supportive immune responses and extension of long-term survival in 21 patients with advanced RCC (60).

In preclinical murine models of mutant-BRAF $\left(\mathrm{BRAF}^{\mathrm{V} 600 \mathrm{E}}\right)$ melanoma, $\mathrm{BRAF}^{\mathrm{V} 600 \mathrm{E}}$ inhibitor vemurafenib synergized with $\mathrm{Th} 1$ cytokines IFN- $\gamma / \mathrm{TNF}-\alpha$ to induce growth arrest (61). In a separate study, vemurafenib reversed $\mathrm{BRAF}^{\mathrm{V} 600 \mathrm{E}}$ melanoma-induced DC dysfunction without deleterious effects on DC viability or capacity to prime T-cell responses in vitro (62), strengthening its candidacy for combination DC-based immunotherapy.

In a murine B16-OVA melanoma model, combination therapy with dasatinib - a RTK inhibitor targeting BCR-ABL, SRC, c-KIT, and PDGFR - and OVA-pulsed DC1 vaccines decreased TME levels of MDSCs and $\mathrm{T}_{\text {reg }}$, enhanced TME recruitment of IL12p70producing DC1, and promoted a profound spreading in the repertoire of tumor-associated antigens recognized by CD ${ }^{+}$TILs (63).

We have recently demonstrated that cooperation between DC1driven Th1 cytokines IFN- $\gamma /$ TNF- $\alpha$ and HER2/neu-targeted antibody trastuzumab is necessary for restoration of MHC class I expression in HER2-overexpressing, but not HER2-low, cancer cells in vitro, thereby facilitating recognition and lysis of these cells by DC1-sensitized HER2-specific $\mathrm{CD}^{+}{ }^{+}$T-cells. Activation of EGFR and HER3 signaling abrogated IFN- $\gamma /$ TNF- $\alpha$ and trastuzumab-induced class I restoration; however, concomitant EGFR/HER3 receptor blockade rescued class I expression and ensuing $\mathrm{CD}^{+}{ }^{+}$T-cell cytotoxicity of HER2/neu-expressing cells (64). Therefore, combinations of DC1-directed Th1 immune interventions and multivalent molecular targeting of HER family members may be essential for optimal HER2/neu-directed immunotherapy.

Collectively, these data provide strong rationale for DCbased combination immunotherapy with oncogene inhibitors in patients with targetable tumors. Indeed, in-human clinical trials investigating such combinations are underway in RCC, breast cancer, and melanoma (Table 1).

\section{Immune Checkpoint Pathway Inhibitors}

Immune checkpoint pathways - which under physiologic conditions prevent aberrantly activated T-cells from mediating autoimmunity - negatively regulate antitumor CTL function, rendering an "exhausted" T-cell phenotype. The CTLA-4/B7 and PD-1/PDL1 pathways are areas of intense investigation. CTLA-4, a CD28 homolog, is upregulated upon T-cell activation and competes with CD28 for binding to APC ligands CD80 (B7.1) and CD86 (B7.2). Inhibitory CTLA-4-driven signaling in T-cells has historically been favored as the leading explanation for the therapeutic benefit of CTLA-4 blockade, reputedly resulting in TCR interference, attenuated IL-2 production, and cell cycle arrest (65, 66). Recent evidence, however, suggests a movement away from these signaling concepts toward a quantitative model of ligand competition, wherein the dominant function of CTLA- 4 is control of CD28 access to shared ligands CD80/CD86 on APC/DCs (67). Intriguingly, the inhibitory function of CTLA-4 may be "domainspecific" - the extracellular, not cytoplasmic domain is sufficient to confer suppressive capacity (68), attenuating stimulatory CD28 signals via direct competition for APC ligands (67). Moreover, CTLA-4 inhibits CD28 co-stimulation by cell-extrinsic depletion of CD80 and CD86 on DCs via trans-endocytosis $(69,70)$; this downregulation can be abrogated either by CTLA- 4 deficiency or blockade (71).

PD-1, a CD28/CTLA-4 homolog, is expressed on T-cells subjected to chronic antigen exposure (e.g., cancer, chronic infection, etc.). Analogous to exhausted T-cell phenotypes observed in murine models of chronic viral infection - which are partially reversed by PD-1 blockade (72) - TILs overexpressing PD-1 are thought to be functionally "exhausted" (73). Conventional wisdom holds that PD-1 binding to its ligands PD-L1/PDL2 - expressed on myeloid cells, DCs, stromal cells, and tumor cells - provides inhibitory signals to T-cells (74). A more nuanced appreciation of PD-1 function, which better informs the therapeutic basis for PD-1 blockade in human cancer, has emerged recently. PD-1:PD-L1 engagement inhibits the TCR-induced "stop signal," resulting in reduced T-cell:DC or T-cell:tumor contact; PD-1 blockade may reverse these effects, abrogate tolerance, and improve tumor targeting $(75,76)$. Moreover, PD-L1 induction on myeloid cells (including DC/APCs) in response to an inflammatory cytokine (e.g., IFN- $\gamma$ ) milieu can impair activation of tumor-specific T-cells $(73,77)$. Blockade of the PD-1:PD-L1 axis may counteract this adaptive resistance, restoring APC function, and enhancing T-cell-targeting of tumors; indeed, PD-L1 expression by infiltrating myeloid, rather than tumor cells was predictive of clinical response to $\mathrm{PD}-1$ pathway blockade in a recently reported phase I study (78). Drawing on provocative evidence from chronic viral infection models, it now appears that PD-1 upregulation may not confer a terminally differentiated "exhausted" state, but rather perpetuates a functionally adapted and stable effector population capable of some degree of tumor control $(79,80)$. Collectively, these data may better explain rescue of T-cell function with PD-1 antagonism.

Monoclonal antibodies (mAb) targeting CTLA-4 and PD-1, therefore, have emerged as an attractive immunostimulatory strategy aimed at recovering $\mathrm{T}$-cell function. In a seminal study, 
administration of anti-CTLA- $4 \mathrm{mAb}$ resulted in the rejection of pre-established tumors, as well as subsequent immunity to tumor rechallenge, in a murine model (81). The success of this, and other preclinical studies, precipitated the development, clinical testing, and subsequent FDA approval of anti-CTLA-4 mAb ipilimumab (82). More recently, preliminary evidence indicates that combination DC-based immunotherapy and CTLA-4 blockade may be synergistic in their benefit. In murine models of osteosarcoma and colorectal cancer, co-administration of anti-CTLA- $4 \mathrm{mAb}$ with either tumor lysate-loaded or immature DCs resulted in tumor growth inhibition, reduced metastasis, and enhanced survival (83, 84). In a phase I study in 16 advanced melanoma patients, coadministration of MART-1-pulsed DCs and anti-CTLA-4 mAb tremelimumab yielded more durable antitumor responses than with either agent alone (85).

The tumor non-specific mechanism of CTLA-4 blockade, however, manifests as dose-limiting toxicity in many patients (86). PD-1 blockade, conversely, is more tumor-specific and generates fewer adverse immune-related effects. Two FDA-approved antiPD-1 mAb nivolumab and pembrolizumab have demonstrated tolerability and encouraging clinical responses in solid tumors (e.g., melanoma, non-small cell lung cancer, colorectal cancer, etc.) $(87,88)$ and hematologic malignancies (89). Approaches combining DC vaccines and PD-1 blockade are on the horizon - in a proof-of-principle study, anti-PD-1 mAb pidilizumab enhanced $\mathrm{CD}^{+}$and $\mathrm{CD}^{+}$T-cell responses following ex vivo stimulation with autologous myeloma-DC fusion vaccines (90). Trials testing pidilizumab in conjunction with DC vaccines in prostate cancer, RCC, and myeloma are underway (Table 1).

A related, but unintended, consequence of DC vaccinationinduced Th1 immunity may be induction of PD-L1 expression on tumors. In our recent study, synergism between Th1 cytokines IFN- $\gamma /$ TNF- $\alpha$ and trastuzumab strongly induced PDL1 expression, in addition to class I upregulation, on HER2overexpressing cells in vitro. While this phenomenon had minimal impact on DC1-sensitized HER2-specific CD8 ${ }^{+}$T-cell-mediated cytotoxicity of cancer cells - likely attributable to minimal PD-1 expression on activated $\mathrm{CD}^{+}$T-cells after limited in vitro $\mathrm{DC} 1$ sensitization (64) - these data justify exploration of a multidimensional therapeutic approach using DC vaccination, targeted therapies, and PD-1/PD-L1 blockade in patients with oncogenedriven tumors.

\section{Muting Immunosuppressive Phenotypes}

In addition to co-inhibitory molecules, tumor-induced suppressive cellular networks (i.e., $\mathrm{T}_{\text {reg }}$ and MDSCs) also inhibit CTL function and mediate escape from immune surveillance. Three broad strategies to counteract $\mathrm{T}_{\text {reg }}$ and MDSCs are plausible. First, inhibiting $\mathrm{T}_{\text {reg }}\left(\mathrm{CD} 4{ }^{+} \mathrm{CD} 25^{+}\right.$Foxp $3^{+}$T-cell $)$may augment $\mathrm{DC}$ efficacy. Antibodies targeting the IL-2 receptor $\alpha$-chain CD25 (e.g., daclizumab, basiliximab) deplete $\mathrm{T}_{\text {reg }}$ and mediate tumor rejection in murine models. However, not only is this $\mathrm{T}_{\text {reg }}$ depletion effect transient but it also appears that these agents may paradoxically impair tumoricidal effector populations. In a phase I/II trial in 30 metastatic melanoma patients, addition of daclizumab to tumor antigen/KLH-pulsed DCs reduced circulating $\mathrm{T}_{\text {reg }}$, but undesirably suppressed tumor-specific CD25 ${ }^{+}$effectors. Progression-free survival was similar between daclizumab-treated vs. untreated patients (91). Denileukin diftitox - another CD25targeting strategy - is a recombinant IL-2-diphtheria toxin conjugate demonstrating $\mathrm{T}_{\text {reg }}$ inhibition in RCC (92) and CEA-overexpressing malignancies (93). Paradoxically, however, denileukin induces a tolerogenic DC phenotype, promotes nonactivated $\mathrm{T}_{\text {reg }}$ survival (94), and inhibits NK cells (95). A nonCD25-based alternative, 1-methyl-D-tryptophan - which inhibits indoleamine-2,3-dioxygenase (IDO) - may overcome these limitations, and is currently being investigated in combination DCbased immunotherapy trials (NCT01042535). In an alternative strategy, mAb targeting the anti-glucocorticoid-induced TNFR family-related receptor (GITR) - expressed highly in $\mathrm{T}_{\text {reg }}$ but not conventional T-cells - in conjunction with HER2/neu-expressing DC vaccines displayed potent antitumor immunity in a tolerogenic murine model (96). While promising, these $\mathrm{T}_{\text {reg-targeting }}$ approaches must consider the risk of depleting $\mathrm{T}_{\text {reg }}$ systemically, which may generate irreversible autoimmunity.

Second, in light of evidence suggesting that MDSCs impair DC vaccine quality (97), concomitant targeting of these elements can be achieved by: (a) promoting MDSC differentiation into non-suppressive cells (e.g., all trans-retinoic acid, vitamin D3); (b) inhibiting myeloid cell development into MDSC (e.g., JAK2/STAT3 inhibitors, zolendronic acid); (c) depleting MDSC levels (e.g., sunitinib, gemcitabine, 5-FU); and (d) disabling MDSC function (e.g., cyclooxygenase-2 inhibitors, PDE5 inhibitors, synthetic triterpenoids) $(98,99)$. Synthetic triterpenoids - such as bardoxolone methyl (CDDO-Me) - can inhibit JAK1/STAT3 signaling and reduce expansion of MDSCs (100). Dual treatment with a survivin-pulsed DC vaccine and CDDO$\mathrm{Me}$, compared with vaccination alone, delayed tumor progression and generated synergistic antigen-specific T-cell responses in EL4 tumor-bearing mice (101).

Finally, DC vaccines can be designed to directly target immunosuppressive elements. Our group has demonstrated that LPS and IFN- $\gamma$-activated DC1 not only negate $\mathrm{T}_{\text {reg }}$ effects but also promote differentiation of these regulators into IFN- $\gamma$-secreting Th1 effectors (102). FoxP3 mRNA-transfected DC vaccines reduced intratumoral, but not systemic, FoxP3 ${ }^{+} \mathrm{T}_{\text {reg }}$ and bolstered TRP2specific CTL responses following co-vaccination with TRP2pulsed DCs in a murine melanoma model (103).

\section{Cytotoxic Chemotherapy}

Increasing recognition of chemotherapy-induced immune effects have fueled the development of "chemoimmunotherapy" regimens that could be explored in conjunction with DC-based vaccination: (a) temozolomide or cyclophosphamide \pm fludarabine reboots the immune system by eliminating immunosuppressive cells and creating an "immune recovery" cytokine (e.g., IL-7, IL-15) environment (44, 104); (b) Metronomically dosed cyclophosphamide depletes $\mathrm{T}_{\text {reg }} / \mathrm{MDSCs}$, increases tumor cell permeability to CTL-derived cytolytic factors, and potentiates Th1 responses (44); (c) gemcitabine enhances tumor-associated antigen cross-presentation, while selectively mediating MDSC apoptosis $(98,105)$. 
While the immune impact of such regimens is recognized, optimal sequencing of chemoimmunotherapy is yet to be definitively established. The potent immunogenicity of DC vaccines makes it an attractive strategy to boost antigenspecific immune responses in heavily pretreated patients - an interim analysis from our ongoing phase I trial investigating HER2-pulsed DC1 vaccination in HER2 ${ }^{\text {pos }}$ breast cancer patients with residual disease following neoadjuvant chemotherapy/trastuzumab demonstrated robust anti-HER2 Th1 immunity 6 months post-vaccination (106). Intriguingly, administration of chemotherapy prior to immunization may even bolster antitumor immunity. In 35 non-Hodgkin's lymphoma patients, pretreatment with cyclophosphamide-containing regimens before tumor-derived idiotype-pulsed DC vaccination induced T-cell and humoral responses as well as generated durable tumor regression (107). Alternatively, DC pre-immunization may sensitize tumors to ensuing cytotoxic effects of chemotherapy. Following initial vaccination with tumor lysate/peptide-pulsed DCs, temozolomide-containing chemotherapy resulted in improved clinical responsivity and survival in glioblastoma patients (108). To confound matters, concomitant chemotherapy and DC vaccination may also be a feasible approach in particular tumor types colon cancer patients concurrently receiving adjuvant oxaliplatin/capecitabine and KLH/CEA-pulsed DCs demonstrated CEA-specific T-cell responses (109). Trials attempting to elucidate the optimal dosing and timing of chemoimmunotherapy are underway (9).

\section{Radiotherapy}

The traditional paradigm of viewing radiotherapy as merely cytoreductive has recently shifted to a more nuanced appreciation of its varied immunomodulatory effects (110). Such effects are exemplified in a recent study in which radiotherapy and dual checkpoint blockade (anti-PD1 plus anti-CTLA-4) demonstrated major tumor regression in metastatic melanoma patients via nonredundant immune mechanisms (111). The mechanistic rationale for addition of radiotherapy to DC-based interventions warrants discussion. Ionizing radiation (a) induces tumor cell apoptosis and necrosis secondary to vascular injury; phagocytosis and crosspresentation of apoptotic bodies by DCs primes tumor-specific T-cell responses if appropriate DC maturation signals are present (112); (b) upregulates expression of class I molecules (113), tumorassociated antigens $(114,115)$, death receptors, and NKG2D ligands on tumors, thereby enabling recognition and elimination of damaged cancer cells that have survived the cytocidal effects of radiotherapy (116); (c) induces generation of proinflammatory cytokines (TNF- $\alpha$, IL-1 $\beta$ ) or endogenous TLR agonists [HMGB1 (TLR4)], which activate DCs and potentiate antitumor inflammatory responses (117); (d) selectively inhibit immunosuppressive cellular $\left(\mathrm{T}_{\text {reg }}\right)$ or soluble (TGF- $\beta$, VEGF) factors (118, 119), thereby enhancing DC functionality; (e) induce immunemediated targeting of tumor stroma $(120,121)$, whereby antigen released after tumor irradiation may be presented by stromal cells for destruction by CTLs; and (f) inhibits distant untreated tumors - the so-called abscopal effect - via immune-mediated mechanisms (122).
This dynamic interplay between irradiated tumor, stromal cells, DCs/APCs, and effector/suppressive immune subsets has set the stage for clinical protocols combining radiotherapy with DC-based immunotherapy. Conformal radiotherapy followed by intratumoral injection of autologous immature DCs in refractory hepatocellular carcinoma patients generated partial responses and improvements in $\alpha$-fetoprotein-specific immune responses in most patients (123). Autologous tumor lysate- or peptidepulsed DCs were combined with intensity-modulated radiotherapy in 40 patients with advanced tumors; nearly two-thirds of patients receiving full-dose radiotherapy demonstrated objective responses (124). Trials investigating DC/radiotherapy protocols are ongoing in brain, breast, pancreatic, and esophageal cancer, as well as melanoma and sarcoma (125).

\section{TLR Agonists and/or Cytokines}

Toll-like receptor agonists and cytokines - by virtue of their ability to regulate lymphocyte homeostasis and potentiate CTL function - are attractive adjuncts to DC-based vaccines. In preclinical studies, administration of TLR3 agonist poly(I:C) and peripheral vaccines resulted in robust Th1-polarized immunity and enhanced CTL activity. In a phase I/II clinical trial, coadministration of poly(I:C) with DC1 vaccines loaded with synthetic glioma-associated antigen epitopes demonstrated immunogenicity and improved progression-free survival in patients with CNS tumors (36). A phase I/II trial evaluating DC1 vaccines with tumor-selective chemokine modulation using poly(I:C) derivative rintatolimod, IFN- $\alpha$, and COX-2 inhibitor celecoxib following resection of peritoneal surface malignancies is currently recruiting patients (NCT02151448). Other promising agents include TLR7/8 agonists (e.g., imiquimod, resiquimod), which stimulate TNF$\alpha /$ IFN- $\alpha$ production by tumor-resident plasmacytoid DCs (126), and TLR9 agonists (e.g., CpG-containing oligodeoxynucleotides), which augment DC activation, enhance TME infiltration by effector T-cells, and inhibit $\mathrm{T}_{\text {reg }}$ /MDSCs in preclinical models (127).

IL-2 is the most extensively studied systemic cytokine adjunct, with encouraging results in combinatorial approaches with DCbased vaccines in preclinical studies (128). Outcomes in the clinical setting are more equivocal - in a phase IB trial in 24 metastatic melanoma patients, treatment with autologous tumor lysatepulsed DC vaccines and IL-2, albeit well tolerated and variably immunogenic, failed to induce meaningful objective responses (129). Other cytokine adjuncts hold promise - in the presence of IL-15, DCs are not only potent APCs but also express CD56 - an NK cell marker - which allow direct tumor cytotoxicity via elaboration of granzyme-B (130). Likewise, IL-7 potentiates DC activation in lymphoid tissue, and enhances TME infiltration of effector T-cells (131). Several combination DC-based immunotherapy trials utilizing these and other (e.g., IL-12, GM-CSF, IFN- $\gamma$, and pegylated-IFN- $\alpha$ ) cytokines are currently underway (Table 1).

\section{Conclusion}

Cancer immunotherapy - in particular, checkpoint inhibitors and genetically engineered T-cell receptor- or chimeric antigen receptor-directed T-cells - has emerged as a central approach 
in the "precision medicine" era. For DC-based immunotherapy to remain relevant in this rapidly changing clinical landscape, the paradigm must shift away from application of DC vaccines as monotherapy for solid tumors. Instead, a multifaceted approach incorporating versatile DC vaccine design and delivery, functionally synergistic targeted molecular and immune adjuncts/therapies, and rationally selected cytotoxic modalities (i.e., chemotherapy, radiotherapy) will yield the clinical outcomes that have remained elusive to date.

\section{Author Contributions}

JD: conception and design, acquisition of data, writing/drafting manuscript, revising for important content, final approval of version to be published; agreement for accountability of published material; EB: acquisition of data, writing/drafting manuscript, revising for important content, final approval of version to be published; agreement for accountability of published material;

\section{References}

1. Palucka K, Banchereau J. Cancer immunotherapy via dendritic cells. Nat Rev Cancer (2012) 12(4):265-77. doi:10.1038/nrc3258

2. Mehta-Damani A, Markowicz S, Engleman EG. Generation of antigen-specific CD8+ CTLs from naive precursors. J Immunol (1994) 153(3):996-1003.

3. Mehta-Damani A, Markowicz S, Engleman EG. Generation of antigen-specific CD4+ T cell lines from naive precursors. Eur J Immunol (1995) 25(5):1206-11. doi:10.1002/eji.1830250511

4. Cintolo JA, Datta J, Mathew SJ, Czerniecki BJ. Dendritic cell-based vaccines: barriers and opportunities. Future Oncol (2012) 8(10):1273-99. doi:10.2217/ fon. 12.125

5. Amigorena S, Savina A. Intracellular mechanisms of antigen cross presentation in dendritic cells. Curr Opin Immunol (2010) 22(1):109-17. doi:10.1016/j.coi. 2010.01.022

6. Carnaud C, Lee D, Donnars O, Park SH, Beavis A, Koezuka Y, et al. Cutting edge: cross-talk between cells of the innate immune system: NKT cells rapidly activate NK cells. J Immunol (1999) 163(9):4647-50.

7. Bonaccorsi I, Pezzino G, Morandi B, Ferlazzo G. Novel perspectives on dendritic cell-based immunotherapy of cancer. Immunol Lett (2013) 155(1-2):6-10. doi:10.1016/j.imlet.2013.09.021

8. Caminschi I, Shortman K. Boosting antibody responses by targeting antigens to dendritic cells. Trends Immunol (2012) 33(2):71-7. doi:10.1016/j.it. 2011.10.007

9. Datta J, Terhune JH, Lowenfeld L, Cintolo JA, Xu S, Roses RE, et al. Optimizing dendritic cell-based approaches for cancer immunotherapy. Yale J Biol Med (2014) 87(4):491-518.

10. Hsu FJ, Benike C, Fagnoni F, Liles TM, Czerwinski D, Taidi B, et al. Vaccination of patients with B-cell lymphoma using autologous antigen-pulsed dendritic cells. Nat Med (1996) 2(1):52-8. doi:10.1038/nm0196-52

11. Nestle FO, Alijagic S, Gilliet M, Sun Y, Grabbe S, Dummer R, et al. Vaccination of melanoma patients with peptide- or tumor lysate-pulsed dendritic cells. Nat Med (1998) 4(3):328-32. doi:10.1038/nm0398-328

12. Anguille S, Smits EL, Lion E, van Tendeloo VF, Berneman ZN. Clinical use of dendritic cells for cancer therapy. Lancet Oncol (2014) 15(7):e257-67. doi:10. 1016/S1470-2045(13)70585-0

13. Kantoff PW, Higano CS, Shore ND, Berger ER, Small EJ, Penson DF, et al. Sipuleucel-T immunotherapy for castration-resistant prostate cancer. $N$ Engl J Med (2010) 363(5):411-22. doi:10.1056/NEJMoa1001294

14. Palucka K, Banchereau J. Dendritic-cell-based therapeutic cancer vaccines. Immunity (2013) 39(1):38-48. doi:10.1016/j.immuni.2013.07.004

15. Tel J, Aarntzen EH, Baba T, Schreibelt G, Schulte BM, Benitez-Ribas D, et al. Natural human plasmacytoid dendritic cells induce antigen-specific T-cell responses in melanoma patients. Cancer Res (2013) 73(3):1063-75. doi:10. 1158/0008-5472.CAN-12-2583
JC: acquisition of data, writing/drafting manuscript, revising for important content, final approval of version to be published; agreement for accountability of published material; SX: acquisition of data, writing/drafting manuscript, revising for important content, final approval of version to be published; agreement for accountability of published material; RR: acquisition of data, writing/drafting manuscript, revising for important content, final approval of version to be published; agreement for accountability of published material; BC: conception and design, acquisition of data, writing/drafting manuscript, revising for important content, final approval of version to be published; agreement for accountability of published material.

\section{Acknowledgments}

Work from our laboratory cited in this review was funded by National Institutes of Health R01 CA096997 and Pennies in Action ${ }^{\circledR}$ Foundation.

16. Jongbloed SL, Kassianos AJ, McDonald KJ, Clark GJ, Ju X, Angel CE, et al. Human CD141+ (BDCA-3)+ dendritic cells (DCs) represent a unique myeloid DC subset that cross-presents necrotic cell antigens. J Exp Med (2010) 207(6):1247-60. doi:10.1084/jem.20092140

17. Evel-Kabler K, Chen SY. Dendritic cell-based tumor vaccines and antigen presentation attenuators. Mol Ther (2006) 13(5):850-8. doi:10.1016/j.ymthe. 2006.02.009

18. Kandalaft LE, Powell DJ Jr, Chiang CL, Tanyi J, Kim S, Bosch M, et al. Autologous lysate-pulsed dendritic cell vaccination followed by adoptive transfer of vaccine-primed ex vivo co-stimulated T cells in recurrent ovarian cancer Oncoimmunology (2013) 2(1):e22664. doi:10.4161/onci.22664

19. Anguille S, Lion E, Van den Bergh J, Van Acker HH, Willemen Y, Smits $\mathrm{EL}$, et al. Interleukin-15 dendritic cells as vaccine candidates for cancer immunotherapy. Hum Vaccin Immunother (2013) 9(9):1956-61. doi:10.4161/ hv. 25373

20. Czerniecki BJ, Koski GK, Koldovsky U, Xu S, Cohen PA, Mick R, et al. Targeting HER-2/neu in early breast cancer development using dendritic cells with staged interleukin-12 burst secretion. Cancer Res (2007) 67(4):1842-52. doi:10.1158/0008-5472.CAN-06-4038

21. Van Nuffel AM, Benteyn D, Wilgenhof S, Corthals J, Heirman C, Neyns B, et al. Intravenous and intradermal TriMix-dendritic cell therapy results in a broad T-cell response and durable tumor response in a chemorefractory stage IVM1c melanoma patient. Cancer Immunol Immunother (2012) 61(7):1033-43. doi:10.1007/s00262-011-1176-2

22. Dudley ME, Yang JC, Sherry R, Hughes MS, Royal R, Kammula U, et al. Adoptive cell therapy for patients with metastatic melanoma: evaluation of intensive myeloablative chemoradiation preparative regimens. J Clin Oncol (2008) 26(32):5233-9. doi:10.1200/JCO.2008.16.5449

23. Besser MJ, Shapira-Frommer R, Treves AJ, Zippel D, Itzhaki O, Hershkovitz $\mathrm{L}$, et al. Clinical responses in a phase II study using adoptive transfer of short-term cultured tumor infiltration lymphocytes in metastatic melanoma patients. Clin Cancer Res (2010) 16(9):2646-55. doi:10.1158/1078-0432. CCR-10-0041

24. Dudley ME, Gross CA, Langhan MM, Garcia MR, Sherry RM, Yang JC, et al. CD8+ enriched "young" tumor infiltrating lymphocytes can mediate regression of metastatic melanoma. Clin Cancer Res (2010) 16(24):6122-31. doi:10.1158/1078-0432.CCR-10-1297

25. Johnson LA, Morgan RA, Dudley ME, Cassard L, Yang JC, Hughes MS, et al. Gene therapy with human and mouse T-cell receptors mediates cancer regression and targets normal tissues expressing cognate antigen. Blood (2009) 114(3):535-46. doi:10.1182/blood-2009-03-211714

26. Kalos M, Levine BL, Porter DL, Katz S, Grupp SA, Bagg A, et al. T cells with chimeric antigen receptors have potent antitumor effects and can establish memory in patients with advanced leukemia. Sci Transl Med (2011) 3(95):95ra73. doi:10.1126/scitranslmed.3002842 
27. Poschke I, Lovgren T, Adamson L, Nystrom M, Andersson E, Hansson J, et al. A phase I clinical trial combining dendritic cell vaccination with adoptive $\mathrm{T}$ cell transfer in patients with stage IV melanoma. Cancer Immunol Immunother (2014) 63(10):1061-71. doi:10.1007/s00262-014-1575-2

28. Lou Y, Wang G, Lizee G, Kim GJ, Finkelstein SE, Feng C, et al. Dendritic cells strongly boost the antitumor activity of adoptively transferred $\mathrm{T}$ cells in vivo. Cancer Res (2004) 64(18):6783-90. doi:10.1158/0008-5472.CAN-04-1621

29. Koike N, Pilon-Thomas S, Mule JJ. Nonmyeloablative chemotherapy followed by $\mathrm{T}$-cell adoptive transfer and dendritic cell-based vaccination results in rejection of established melanoma. J Immunother (2008) 31(4):402-12. doi:10. 1097/CJI.0b013e31816cabbb

30. Song S, Zhang K, You H, Wang J, Wang Z, Yan C, et al. Significant anti-tumour activity of adoptively transferred $\mathrm{T}$ cells elicited by intratumoral dendritic cell vaccine injection through enhancing the ratio of CD8(+) $\mathrm{T}$ cell/regulatory $\mathrm{T}$ cells in tumour. Clin Exp Immunol (2010) 162(1):75-83. doi:10.1111/j. 1365-2249.2010.04226.x

31. Lutz-Nicoladoni C, Wallner S, Stoitzner P, Pircher M, Gruber T, Wolf AM, et al. Reinforcement of cancer immunotherapy by adoptive transfer of cblbdeficient CD8+ T cells combined with a DC vaccine. Immunol Cell Biol (2012) 90(1):130-4. doi:10.1038/icb.2011.11

32. Chodon T, Comin-Anduix B, Chmielowski B, Koya RC, Wu Z, Auerbach M, et al. Adoptive transfer of MART-1 T-cell receptor transgenic lymphocytes and dendritic cell vaccination in patients with metastatic melanoma. Clin Cancer Res (2014) 20(9):2457-65. doi:10.1158/1078-0432.CCR-13-3017

33. Koski GK, Koldovsky U, Xu S, Mick R, Sharma A, Fitzpatrick E, et al. A novel dendritic cell-based immunization approach for the induction of durable Th1-polarized anti-HER-2/neu responses in women with early breast cancer. J Immunother (2012) 35(1):54-65. doi:10.1097/CJI.0b013e318235f512

34. Dohnal AM, Graffi S, Witt V, Eichstill C, Wagner D, Ul-Haq S, et al. Comparative evaluation of techniques for the manufacturing of dendritic cell-based cancer vaccines. J Cell Mol Med (2009) 13(1):125-35. doi:10.1111/j.1582-4934. 2008.00304.x

35. Carreno BM, Becker-Hapak M, Huang A, Chan M, Alyasiry A, Lie WR, et al. IL-12p70-producing patient DC vaccine elicits Tc1-polarized immunity. J Clin Invest (2013) 123(8):3383-94. doi:10.1172/JCI68395

36. Okada H, Kalinski P, Ueda R, Hoji A, Kohanbash G, Donegan TE, et al. Induction of CD8+ T-cell responses against novel glioma-associated antigen peptides and clinical activity by vaccinations with \{alpha\}-type 1 polarized dendritic cells and polyinosinic-polycytidylic acid stabilized by lysine and carboxymethylcellulose in patients with recurrent malignant glioma. J Clin Oncol (2011) 29(3):330-6. doi:10.1200/JCO.2010.30.7744

37. Chan SH, Perussia B, Gupta JW, Kobayashi M, Pospisil M, Young HA, et al. Induction of interferon gamma production by natural killer cell stimulatory factor: characterization of the responder cells and synergy with other inducers. J Exp Med (1991) 173(4):869-79. doi:10.1084/jem.173.4.869

38. Voest EE, Kenyon BM, O'Reilly MS, Truitt G, D’Amato RJ, Folkman J. Inhibition of angiogenesis in vivo by interleukin 12. J Natl Cancer Inst (1995) 87(8):581-6. doi:10.1093/jnci/87.8.581

39. Xu S, Koski GK, Faries M, Bedrosian I, Mick R, Maeurer M, et al. Rapid high efficiency sensitization of CD8+ T cells to tumor antigens by dendritic cells leads to enhanced functional avidity and direct tumor recognition through an IL-12-dependent mechanism. J Immunol (2003) 171(5):2251-61. doi:10.4049/ jimmunol.171.5.2251

40. Nanni P, Landuzzi L, Nicoletti G, De Giovanni C, Rossi I, Croci S, et al. Immunoprevention of mammary carcinoma in HER-2/neu transgenic mice is IFN-gamma and B cell dependent. J Immunol (2004) 173(4):2288-96. doi:10. 4049/jimmunol.173.4.2288

41. Datta J, Rosemblit C, Berk E, Showalter L, Namjoshi P, Mick R, et al. Progressive loss of anti-HER2 CD4+ T-helper type 1 response in breast tumorigenesis and the potential for immune restoration. Oncoimmunology (2015) 4(8):e1022301. doi:10.1080/2162402X.2015.1022301

42. Czerniecki BJ, Roses RE, Koski GK. Development of vaccines for high-risk ductal carcinoma in situ of the breast. Cancer Res (2007) 67(14):6531-4. doi:10.1158/0008-5472.CAN-07-0878

43. Langenkamp A, Messi M, Lanzavecchia A, Sallusto F. Kinetics of dendritic cell activation: impact on priming of TH1, TH2 and nonpolarized T cells. Nat Immunol (2000) 1(4):311-6. doi:10.1038/79758

44. Strioga MM, Felzmann T, Powell DJ Jr, Ostapenko V, Dobrovolskiene NT, Matuskova M, et al. Therapeutic dendritic cell-based cancer vaccines: the state of the art. Crit Rev Immunol (2013) 33(6):489-547. doi:10.1615/ CritRevImmunol.2013008033

45. Bedrosian I, Mick R, Xu S, Nisenbaum H, Faries M, Zhang P, et al. Intranodal administration of peptide-pulsed mature dendritic cell vaccines results in superior CD8+ T-cell function in melanoma patients. J Clin Oncol (2003) 21(20):3826-35. doi:10.1200/JCO.2003.04.042

46. Koski GK, Cohen PA, Roses RE, Xu S, Czerniecki BJ. Reengineering dendritic cell-based anti-cancer vaccines. Immunol Rev (2008) 222:256-76. doi:10.1111/ j.1600-065X.2008.00617.x

47. Cella M, Scheidegger D, Palmer-Lehmann K, Lane P, Lanzavecchia A, Alber G. Ligation of CD40 on dendritic cells triggers production of high levels of interleukin-12 and enhances T cell stimulatory capacity: T-T help via APC activation. J Exp Med (1996) 184(2):747-52. doi:10.1084/jem.184.2.747

48. Ridge JP, Di Rosa F, Matzinger P. A conditioned dendritic cell can be a temporal bridge between a CD4+ T-helper and a T-killer cell. Nature (1998) 393(6684):474-8. doi:10.1038/30989

49. Clarke SR. The critical role of CD40/CD40L in the CD4-dependent generation of CD8+ T cell immunity. J Leukoc Biol (2000) 67(5):607-14

50. Hernandez MG, Shen L, Rock KL. CD40-CD40 ligand interaction between dendritic cells and CD8+ $\mathrm{T}$ cells is needed to stimulate maximal $\mathrm{T}$ cell responses in the absence of CD4+ $\mathrm{T}$ cell help. J Immunol (2007) 178(5):2844-52. doi:10.4049/jimmunol.178.5.2844

51. Ma DY, Clark EA. The role of CD40 and CD154/CD40L in dendritic cells. Semin Immunol (2009) 21(5):265-72. doi:10.1016/j.smim.2009.05.010

52. Martin S, Agarwal R, Murugaiyan G, Saha B. CD40 expression levels modulate regulatory $\mathrm{T}$ cells in Leishmania donovani infection. J Immunol (2010) 185(1):551-9. doi:10.4049/jimmunol.0902206

53. Bhadra R, Gigley JP, Khan IA. Cutting edge: CD40-CD40 ligand pathway plays a critical CD8-intrinsic and -extrinsic role during rescue of exhausted CD8 T cells. J Immunol (2011) 187(9):4421-5. doi:10.4049/jimmunol.1102319

54. Dohnal AM, Luger R, Paul P, Fuchs D, Felzmann T. CD40 ligation restores type 1 polarizing capacity in TLR4-activated dendritic cells that have ceased interleukin-12 expression. J Cell Mol Med (2009) 13(8B):1741-50. doi:10.1111/ j.1582-4934.2008.00584.x

55. Abdi K, Singh NJ, Matzinger P. Lipopolysaccharide-activated dendritic cells: "exhausted" or alert and waiting? J Immunol (2012) 188(12):5981-9. doi:10. 4049/jimmunol.1102868

56. Wilgenhof S, Van Nuffel AM, Benteyn D, Corthals J, Aerts C, Heirman C, et al. A phase IB study on intravenous synthetic mRNA electroporated dendritic cell immunotherapy in pretreated advanced melanoma patients. Ann Oncol (2013) 24(10):2686-93. doi:10.1093/annonc/mdt245

57. Vanneman M, Dranoff G. Combining immunotherapy and targeted therapies in cancer treatment. Nat Rev Cancer (2012) 12(4):237-51. doi:10.1038/ nrc3237

58. Ko JS, Zea AH, Rini BI, Ireland JL, Elson P, Cohen P, et al. Sunitinib mediates reversal of myeloid-derived suppressor cell accumulation in renal cell carcinoma patients. Clin Cancer Res (2009) 15(6):2148-57. doi:10.1158/1078-0432. CCR-08-1332

59. Ozao-Choy J, Ma G, Kao J, Wang GX, Meseck M, Sung M, et al. The novel role of tyrosine kinase inhibitor in the reversal of immune suppression and modulation of tumor microenvironment for immune-based cancer therapies. Cancer Res (2009) 69(6):2514-22. doi:10.1158/0008-5472.CAN-08-4709

60. Amin A, Dudek AZ, Logan TF, Lance RS, Holzbeierlein JM, Knox JJ, et al. Survival with AGS-003, an autologous dendritic cell-based immunotherapy, in combination with sunitinib in unfavorable risk patients with advanced renal cell carcinoma (RCC): phase 2 study results. J Immunother Cancer (2015) 3:14. doi:10.1186/s40425-015-0055-3

61. Acquavella N, Clever D, Yu Z, Roelke-Parker M, Palmer DC, Xi L, et al. Type I cytokines synergize with oncogene inhibition to induce tumor growth arrest Cancer Immunol Res (2015) 3(1):37-47. doi:10.1158/2326-6066.CIR-14-0122

62. Ott PA, Henry T, Baranda SJ, Frleta D, Manches O, Bogunovic D, et al. Inhibition of both BRAF and MEK in BRAF(V600E) mutant melanoma restores compromised dendritic cell (DC) function while having differential direct effects on DC properties. Cancer Immunol Immunother (2013) 62(4):811-22. doi:10.1007/s00262-012-1389-z

63. Lowe DB, Bose A, Taylor JL, Tawbi H, Lin Y, Kirkwood JM, et al. Dasatinib promotes the expansion of a therapeutically superior T-cell repertoire in response to dendritic cell vaccination against melanoma. Oncoimmunology (2014) 3(1):e27589. doi:10.4161/onci.27589 
64. Datta J, Xu S, Rosemblit C, Smith JB, Cintolo JA, Powell D Jr, et al. CD4+ T-helper type 1 cytokines and trastuzumab facilitate CD8+ $\mathrm{t}$-cell targeting of her-2/neu-expressing cancers. Cancer Immunol Res (2015) 3(5):455-63. doi:10.1158/2326-6066.CIR-14-0208

65. Krummel MF, Allison JP. CTLA-4 engagement inhibits IL-2 accumulation and cell cycle progression upon activation of resting T cells. J Exp Med (1996) 183(6):2533-40. doi:10.1084/jem.183.6.2533

66. Alegre ML, Frauwirth KA, Thompson CB. T-cell regulation by CD28 and CTLA-4. Nat Rev Immunol (2001) 1(3):220-8. doi:10.1038/35105024

67. Walker LS, Sansom DM. Confusing signals: recent progress in CTLA-4 biology. Trends Immunol (2015) 36(2):63-70. doi:10.1016/j.it.2014.12.001

68. Yamaguchi T, Kishi A, Osaki M, Morikawa H, Prieto-Martin P, Wing K, et al. Construction of self-recognizing regulatory $\mathrm{T}$ cells from conventional $\mathrm{T}$ cells by controlling CTLA-4 and IL-2 expression. Proc Natl Acad Sci U S A (2013) 110(23):E2116-25. doi:10.1073/pnas.1307185110

69. Oderup C, Cederbom L, Makowska A, Cilio CM, Ivars F. Cytotoxic T lymphocyte antigen-4-dependent down-modulation of costimulatory molecules on dendritic cells in CD4+ CD25+ regulatory T-cell-mediated suppression. Immunology (2006) 118(2):240-9. doi:10.1111/j.1365-2567.2006.02362.x

70. Qureshi OS, Zheng Y, Nakamura K, Attridge K, Manzotti C, Schmidt EM, et al. Trans-endocytosis of CD80 and CD86: a molecular basis for the cellextrinsic function of CTLA-4. Science (2011) 332(6029):600-3. doi:10.1126/ science. 1202947

71. Wing K, Onishi Y, Prieto-Martin P, Yamaguchi T, Miyara M, Fehervari Z, et al. CTLA-4 control over Foxp3+ regulatory T cell function. Science (2008) 322(5899):271-5. doi:10.1126/science.1160062

72. Barber DL, Wherry EJ, Masopust D, Zhu B, Allison JP, Sharpe AH, et al. Restoring function in exhausted CD8 T cells during chronic viral infection. Nature (2006) 439(7077):682-7. doi:10.1038/nature04444

73. Topalian SL, Drake CG, Pardoll DM. Immune checkpoint blockade: a common denominator approach to cancer therapy. Cancer Cell (2015) 27(4):450-61. doi:10.1016/j.ccell.2015.03.001

74. Keir ME, Francisco LM, Sharpe AH. PD-1 and its ligands in T-cell immunity. Curr Opin Immunol (2007) 19(3):309-14. doi:10.1016/j.coi.2007.04.012

75. Fife BT, Pauken KE, Eagar TN, Obu T, Wu J, Tang Q, et al. Interactions between PD-1 and PD-L1 promote tolerance by blocking the TCR-induced stop signal. Nat Immunol (2009) 10(11):1185-92. doi:10.1038/ni.1790

76. Diepolder H, Obst R. Making antigen invisible: a coinhibitory molecule regulates the interaction between T cells and dendritic cells. Expert Rev Vaccines (2010) 9(3):243-7. doi:10.1586/erv.09.164

77. Llosa NJ, Cruise M, Tam A, Wicks EC, Hechenbleikner EM, Taube JM, et al. The vigorous immune microenvironment of microsatellite instable colon cancer is balanced by multiple counter-inhibitory checkpoints. Cancer Discov (2015) 5(1):43-51. doi:10.1158/2159-8290.CD-14-0863

78. Herbst RS, Soria JC, Kowanetz M, Fine GD, Hamid O, Gordon MS, et al. Predictive correlates of response to the anti-PD-L1 antibody MPDL3280A in cancer patients. Nature (2014) 515(7528):563-7. doi:10.1038/nature14011

79. West EE, Jin HT, Rasheed AU, Penaloza-Macmaster P, Ha SJ, Tan WG, et al. PD-L1 blockade synergizes with IL-2 therapy in reinvigorating exhausted T cells. J Clin Invest (2013) 123(6):2604-15. doi:10.1172/JCI67008

80. Speiser DE, Utzschneider DT, Oberle SG, Munz C, Romero P, Zehn D. T cell differentiation in chronic infection and cancer: functional adaptation or exhaustion? Nat Rev Immunol (2014) 14(11):768-74. doi:10.1038/nri3740

81. Leach DR, Krummel MF, Allison JP. Enhancement of antitumor immunity by CTLA-4 blockade. Science (1996) 271(5256):1734-6. doi:10.1126/science.271. 5256.1734

82. Hodi FS, O’Day SJ, McDermott DF, Weber RW, Sosman JA, Haanen JB, et al. Improved survival with ipilimumab in patients with metastatic melanoma. $N$ Engl J Med (2010) 363(8):711-23. doi:10.1056/NEJMoa1003466

83. Kawano M, Itonaga I, Iwasaki T, Tsumura H. Enhancement of antitumor immunity by combining anti-cytotoxic Tlymphocyte antigen- 4 antibodies and cryotreated tumor lysate-pulsed dendritic cells in murine osteosarcoma. Oncol Rep (2013) 29(3):1001-6. doi:10.3892/or.2013.2224

84. Son CH, Bae JH, Shin DY, Lee HR, Choi YJ, Jo WS, et al. CTLA-4 blockade enhances antitumor immunity of intratumoral injection of immature dendritic cells into irradiated tumor in a mouse colon cancer model. J Immunother (2014) 37(1):1-7. doi:10.1097/CJI.0000000000000007

85. Ribas A, Comin-Anduix B, Chmielowski B, Jalil J, de la Rocha P, McCannel TA, et al. Dendritic cell vaccination combined with CTLA4 blockade in patients with metastatic melanoma. Clin Cancer Res (2009) 15(19):6267-76. doi:10.1158/1078-0432.CCR-09- 1254

86. Di Giacomo AM, Biagioli M, Maio M. The emerging toxicity profiles of anti-CTLA-4 antibodies across clinical indications. Semin Oncol (2010) 37(5):499-507. doi:10.1053/j.seminoncol.2010.09.007

87. Topalian SL, Hodi FS, Brahmer JR, Gettinger SN, Smith DC, McDermott DF, et al. Safety, activity, and immune correlates of anti-PD-1 antibody in cancer. N Engl J Med (2012) 366(26):2443-54. doi:10.1056/NEJMoa1200690

88. Hamid O, Robert C, Daud A, Hodi FS, Hwu WJ, Kefford R, et al. Safety and tumor responses with lambrolizumab (anti-PD-1) in melanoma. N Engl J Med (2013) 369(2):134-44. doi:10.1056/NEJMoa1305133

89. Ansell SM, Lesokhin AM, Borrello I, Halwani A, Scott EC, Gutierrez M, et al. PD-1 blockade with nivolumab in relapsed or refractory Hodgkin's lymphoma. N Engl J Med (2015) 372(4):311-9. doi:10.1056/NEJMoa1411087

90. Rosenblatt J, Glotzbecker B, Mills H, Vasir B, Tzachanis D, Levine JD, et al. PD1 blockade by CT-011, anti-PD-1 antibody, enhances ex vivo T-cell responses to autologous dendritic cell/myeloma fusion vaccine. J Immunother (2011) 34(5):409-18. doi:10.1097/CJI.0b013e31821ca6ce

91. Jacobs JF, Punt CJ, Lesterhuis WJ, Sutmuller RP, Brouwer HM, Scharenborg NM, et al. Dendritic cell vaccination in combination with anti-CD25 monoclonal antibody treatment: a phase I/II study in metastatic melanoma patients. Clin Cancer Res (2010) 16(20):5067-78. doi:10.1158/1078-0432. CCR-10- 1757

92. Dannull J, Su Z, Rizzieri D, Yang BK, Coleman D, Yancey D, et al. Enhancement of vaccine-mediated antitumor immunity in cancer patients after depletion of regulatory T cells. J Clin Invest (2005) 115(12):3623-33. doi:10.1172/ JCI25947

93. Morse MA, Hobeika AC, Osada T, Serra D, Niedzwiecki D, Lyerly HK, et al. Depletion of human regulatory $\mathrm{T}$ cells specifically enhances antigen-specific immune responses to cancer vaccines. Blood (2008) 112(3):610-8. doi:10. 1182/blood-2008-01-135319

94. Baur AS, Lutz MB, Schierer S, Beltrame L, Theiner G, Zinser E, et al. Denileukin diftitox (ONTAK) induces a tolerogenic phenotype in dendritic cells and stimulates survival of resting Treg. Blood (2013) 122(13):2185-94. doi:10.1182/blood-2012-09-456988

95. Yamada Y, Aoyama A, Tocco G, Boskovic S, Nadazdin O, Alessandrini A, et al. Differential effects of denileukin diftitox IL-2 immunotoxin on NK and regulatory T cells in nonhuman primates. J Immunol (2012) 188(12):6063-70. doi:10.4049/jimmunol.1200656

96. Ko HJ, Kim YJ, Kim YS, Chang WS, Ko SY, Chang SY, et al. A combination of chemoimmunotherapies can efficiently break self-tolerance and induce antitumor immunity in a tolerogenic murine tumor model. Cancer Res (2007) 67(15):7477-86. doi:10.1158/0008-5472.CAN-06-4639

97. Poschke I, Mao Y, Adamson L, Salazar-Onfray F, Masucci G, Kiessling R. Myeloid-derived suppressor cells impair the quality of dendritic cell vaccines. Cancer Immunol Immunother (2012) 61(6):827-38. doi:10.1007/ s00262-011-1143-y

98. Najjar YG, Finke JH. Clinical perspectives on targeting of myeloid derived suppressor cells in the treatment of cancer. Front Oncol (2013) 3:49. doi:10. 3389/fonc. 2013.00049

99. Wesolowski R, Markowitz J, Carson WE III. Myeloid derived suppressor cells a new therapeutic target in the treatment of cancer. Jimmunother cancer (2013) 1:10. doi:10.1186/2051-1426-1-10

100. Ahmad R, Raina D, Meyer C, Kufe D. Triterpenoid CDDO-methyl ester inhibits the Janus-activated kinase-1 (JAK1) - > signal transducer and activator of transcription-3 (STAT3) pathway by direct inhibition of JAK1 and STAT3. Cancer Res (2008) 68(8):2920-6. doi:10.1158/0008-5472. CAN-07-3036

101. Nagaraj S, Youn JI, Weber H, Iclozan C, Lu L, Cotter MJ, et al. Anti-inflammatory triterpenoid blocks immune suppressive function of MDSCs and improves immune response in cancer. Clin Cancer Res (2010) 16(6):1812-23. doi:10.1158/1078-0432.CCR-09-3272

102. Lee MKt, Xu S, Fitzpatrick EH, Sharma A, Graves HL, Czerniecki BJ. Inhibition of $\mathrm{CD} 4+\mathrm{CD} 25+$ regulatory $\mathrm{T}$ cell function and conversion into Th1-like effectors by a Toll-like receptor-activated dendritic cell vaccine. PLoS One (2013) 8(11):e74698. doi:10.1371/journal.pone.0074698

103. Nair S, Boczkowski D, Fassnacht M, Pisetsky D, Gilboa E. Vaccination against the forkhead family transcription factor Foxp3 enhances tumor immunity. Cancer Res (2007) 67(1):371-80. doi:10.1158/0008-5472.CAN-06-2903 
104. Ridolfi L, Petrini M, Granato AM, Gentilcore G, Simeone E, Ascierto $\mathrm{PA}$, et al. Low-dose temozolomide before dendritic-cell vaccination reduces (specifically) CD4+CD25++Foxp3+ regulatory T-cells in advanced melanoma patients. J Transl Med (2013) 11:135. doi:10.1186/1479-5876-11-135

105. Nowak AK, Lake RA, Marzo AL, Scott B, Heath WR, Collins EJ, et al. Induction of tumor cell apoptosis in vivo increases tumor antigen cross-presentation, cross-priming rather than cross-tolerizing host tumor-specific CD8 T cells. $J$ Immunol (2003) 170(10):4905-13. doi:10.4049/jimmunol.170.10.4905

106. Datta J, Berk E, Xu S, Fitzpatrick E, Rosemblit C, Lowenfeld L, et al. Anti-HER2 $\mathrm{CD} 4+\mathrm{T}$-helper type 1 response is a novel immune correlate to pathologic response following neoadjuvant therapy in her2-positive breast cancer. Breast Cancer Res (2015) 17:71. doi:10.1186/s13058-015-0584- 1

107. Timmerman JM, Czerwinski DK, Davis TA, Hsu FJ, Benike C, Hao ZM, et al. Idiotype-pulsed dendritic cell vaccination for B-cell lymphoma: clinical and immune responses in 35 patients. Blood (2002) 99(5):1517-26. doi:10.1182/ blood.V99.5.1517

108. Wheeler CJ, Das A, Liu G, Yu JS, Black KL. Clinical responsiveness of glioblastoma multiforme to chemotherapy after vaccination. Clin Cancer Res (2004) 10(16):5316-26. doi:10.1158/1078-0432.CCR-04-0497

109. Lesterhuis WJ, de Vries IJ, Aarntzen EA, de Boer A, Scharenborg NM, van de Rakt M, et al. A pilot study on the immunogenicity of dendritic cell vaccination during adjuvant oxaliplatin/capecitabine chemotherapy in colon cancer patients. Br J Cancer (2010) 103(9):1415-21. doi:10.1038/sj.bjc.6605935

110. Roses RE, Datta J, Czerniecki BJ. Radiation as immunomodulator: implications for dendritic cell-based immunotherapy. Radiat Res (2015) 182(2):211-8. doi:10.1667/RR13495.1

111. Twyman-Saint Victor C, Rech AJ, Maity A, Rengan R, Pauken KE, Stelekati E, et al. Radiation and dual checkpoint blockade activate non-redundant immune mechanisms in cancer. Nature (2015) 520(7547):373-7. doi:10.1038/ nature 14292

112. Roses RE, Xu M, Koski GK, Czerniecki BJ. Radiation therapy and Toll-like receptor signaling: implications for the treatment of cancer. Oncogene (2008) 27(2):200-7. doi:10.1038/sj.onc.1210909

113. Hauser SH, Calorini L, Wazer DE, Gattoni-Celli S. Radiation-enhanced expression of major histocompatibility complex class I antigen $\mathrm{H}-2 \mathrm{Db}$ in B16 melanoma cells. Cancer Res (1993) 53(8):1952-5.

114. Hareyama M, Imai K, Kubo K, Takahashi H, Koshiba H, Hinoda Y, et al. Effect of radiation on the expression of carcinoembryonic antigen of human gastric adenocarcinoma cells. Cancer (1991) 67(9):2269-74. doi:10.1002/ 1097-0142(19910501)67:9<2269::AID-CNCR2820670910>3.0.CO;2-Z

115. Matsumoto H, Takahashi T, Mitsuhashi N, Higuch K, Niibe H. Modification of tumor-associated antigen (CEA) expression of human lung cancer cells by irradiation, either alone or in combination with interferon-gamma. Anticancer Res (1999) 19(1A):307-11.

116. Demaria S, Pilones KA, Vanpouille-Box C, Golden EB, Formenti SC. The optimal partnership of radiation and immunotherapy: from preclinical studies to clinical translation. Radiat Res (2014) 182(2):170-81. doi:10.1667/ RR13500.1

117. Schaue D, Micewicz ED, Ratikan JA, Xie MW, Cheng G, McBride WH. Radiation and inflammation. Semin Radiat Oncol (2015) 25(1):4-10. doi:10. 1016/j.semradonc.2014.07.007

118. Dunn PL, North RJ. Selective radiation resistance of immunologically induced $\mathrm{T}$ cells as the basis for irradiation-induced T-cell-mediated regression of immunogenic tumor. J Leukoc Biol (1991) 49(4):388-96.

119. Teitz-Tennenbaum S, Li Q, Okuyama R, Davis MA, Sun R, Whitfield $\mathrm{J}$, et al. Mechanisms involved in radiation enhancement of intratumoral dendritic cell therapy. J Immunother (2008) 31(4):345-58. doi:10.1097/CJI ob013e318163628c

120. Hallahan DE, Staba-Hogan MJ, Virudachalam S, Kolchinsky A. X-ray-induced P-selectin localization to the lumen of tumor blood vessels. Cancer Res (1998) 58(22):5216-20.

121. Zhang B, Bowerman NA, Salama JK, Schmidt H, Spiotto MT, Schietinger A, et al. Induced sensitization of tumor stroma leads to eradication of established cancer by T cells. J Exp Med (2007) 204(1):49-55. doi:10.1084/jem.20062056

122. Formenti SC, Demaria S. Systemic effects of local radiotherapy. Lancet Oncol (2009) 10(7):718-26. doi:10.1016/S1470-2045(09)70082-8

123. Chi KH, Liu SJ, Li CP, Kuo HP, Wang YS, Chao Y, et al. Combination of conformal radiotherapy and intratumoral injection of adoptive dendritic cell immunotherapy in refractory hepatoma. J Immunother (2005) 28(2):129-35. doi:10.1097/01.cji.0000154248.74383.5e

124. Shibamoto Y, Okamoto M, Kobayashi M, Ayakawa S, Iwata H, Sugie C, et al. Immune-maximizing (IMAX) therapy for cancer: combination of dendritic cell vaccine and intensity-modulated radiation. Mol Clin Oncol (2013) 1(4):649-54. doi:10.3892/mco.2013.108

125. Crittenden M, Kohrt H, Levy R, Jones J, Camphausen K, Dicker A, et al. Current clinical trials testing combinations of immunotherapy and radiation. Semin Radiat Oncol (2015) 25(1):54-64. doi:10.1016/j.semradonc.2014.07.003

126. Miller RL, Gerster JF, Owens ML, Slade HB, Tomai MA. Imiquimod applied topically: a novel immune response modifier and new class of drug. Int Immunopharmacol (1999) 21(1):1-14. doi:10.1016/S0192-0561(98)00068-X

127. Chang LS, Leng CH, Yeh YC, Wu CC, Chen HW, Huang HM, et al. Tolllike receptor 9 agonist enhances anti-tumor immunity and inhibits tumorassociated immunosuppressive cells numbers in a mouse cervical cancer model following recombinant lipoprotein therapy. Mol Cancer (2014) 13:60. doi:10.1186/1476-4598-13-60

128. Shimizu K, Fields RC, Giedlin M, Mule JJ. Systemic administration of interleukin 2 enhances the therapeutic efficacy of dendritic cell-based tumor vaccines. Proc Natl Acad Sci U S A (1999) 96(5):2268-73. doi:10.1073/pnas. 96.5.2268

129. Redman BG, Chang AE, Whitfield J, Esper P, Jiang G, Braun T, et al. Phase Ib trial assessing autologous, tumor-pulsed dendritic cells as a vaccine administered with or without IL-2 in patients with metastatic melanoma. J Immunother (2008) 31(6):591-8. doi:10.1097/CJI.0b013e31817fd90b

130. Anguille S, Lion E, Tel J, de Vries IJ, Coudere K, Fromm PD, et al. Interleukin15-induced CD56(+) myeloid dendritic cells combine potent tumor antigen presentation with direct tumoricidal potential. PLoS One (2012) 7(12):e51851 doi:10.1371/journal.pone.0051851

131. Li B, VanRoey MJ, Jooss K. Recombinant IL-7 enhances the potency of GM-CSF-secreting tumor cell immunotherapy. Clin Immunol (2007) 123(2):155-65. doi:10.1016/j.clim.2007.01.002

Conflict of Interest Statement: The authors declare that the research was conducted in the absence of any commercial or financial relationships that could be construed as a potential conflict of interest.

Copyright (C) 2015 Datta, Berk, Cintolo, Xu, Roses and Czerniecki. This is an openaccess article distributed under the terms of the Creative Commons Attribution License (CC BY). The use, distribution or reproduction in other forums is permitted, provided the original author(s) or licensor are credited and that the original publication in this journal is cited, in accordance with accepted academic practice. No use, distribution or reproduction is permitted which does not comply with these terms. 